\title{
The End of the Myth of the Cuban Exile? Current Trends in Cuban Emigration
}

\author{
Katarzyna Dembicz \\ (iD) https://orcid.org/0000-0002-8023-088X \\ University of Warsaw \\ American Studies Center \\ e-mail:khdembic@uw.edu.pl
}

\section{Abstract}

Cuban migrants are considered as and referred to as exiles. However, in the face of the economic transformations in Cuba, as well as the rapprochement between the U.S. and Cuba, it has become necessary to revise the epistemological and semiotic foundations of this phenomenon. The current migratory trends among the Cubans do not meet the definition of exiles. Thus, the title of this article reflects the research assumption and the principal aim that the current circumstances in Cuba, as well as the migratory flows of Cubans mark the decline of the myth of the Cuban exile; a myth built by the media.

Keywords: Cuba, exile, Cuban diaspora, myth, Roland Barthes 


\section{Introduction}

The subject of migrations eludes disciplinary paradigms and is analysed today from multi- and interdisciplinary perspectives. Such is the case of the Cuban society, which has been witnessing the phenomenon of migration for decades, and suffers from a division between the insular population and the diaspora. It is a demographic, social, and political process, in which the relations between Cuba and the United States - apart from the internal political constraints - contributed greatly to the creation of a strong Cuban community abroad, referred to as the exiles.

Although the terms diaspora and exile are closely linked, it is necessary to differentiate between those. As Nico Israel argues in his work entitled Outlandish Writing Between Exile and Diaspora (Israel 200o), both terms share the experience of forced emigration with no perspectives of returning. The term exile indicates the expulsion of persons from a place under pressure - institutional at times - which renders it a political act. Meanwhile, the term diaspora refers to the spiritual sphere of suffering and yearning for the homeland and indicates the destination, where the émigrés create a community that preserves the memories, as well as the collective and the individual links to the place of origin. An extensive discussion of the definitions of migration and research methods related to it go beyond the scope of the article, whose focus remains on the evolution and existence of the myth of the Cuban exile.

Cuban migrants, scattered around the world, have been considered and referred to as exiles. However, in the face of the political and economic transformations in Cuba, as well as the rapprochement between the United States and Cuba (in the years 2013-2017), it has become necessary to revise the epistemological and semiotic foundations of this phenomenon. In the light of the rapprochement, and based on the observations and the analyses carried out throughout the last decade, I came to a conclusion that the current migratory trends among the Cubans do not meet the definition of exile, which will be explained in the following paragraphs. Thus, the title of this article reflects the research assumption that the current political, economic, and social circumstances in Cuba - a country set in a multipolar and multicentric world of international relations - as well as the migratory flows of contemporary Cubans mark the decline of the myth of the Cuban exile; a myth built by the media, based on the individual and the collective histories and events (throughout the 2oth century), and exploited by a variety of social actors especially in advancing their political agendas. Given these research objectives, the concepts of Roland Barthes have become highly relevant. In his work Mythologies Barthes (1999) developed the theoretical framework for the creation of the modern imagery and broadened the knowledge on the building of contemporary myths, as well as the way these myths are handled by diverse social actors.

The first section of this text will present the current migratory trends, focusing on two phenomena: the intense flow of Cubans to the United States via Central 
America and Mexico and, subsequently, their returns to Cuba. The second part is dedicated to Roland Barthes's concept of myth. Finally, looking from the modern myth-perspective, we will present arguments that support the idea that the current migratory trends, the socio-economic situation of Cuba, as well as the international context, contribute to the exhaustion of the myth of Cuban exile and its invalidity in terms of its function.

\section{Review of the state of research on migration and Cuban exile}

Research on the Caribbean and especially Cuban migrations abroad have a long tradition and are very rich in content. I mention the Caribbean region since comparative analyses have frequently been developed in order to expose the uniqueness of the Cuban migratory phenomenon, which until recently has been considered political, but which today is classified as voluntary, when economic and social factors are those that prevail in the decision to emigrate. Among contemporary researchers, it is enough to mention Jorge Duany, Holly Ackerman, Silvia Pedraza or Sergio DiazBarquets, who continuously work with the Cuban diaspora, emigration flows and Cuban-American relations. The interdisciplinarity that characterises the investigations of the largest academic centres such as the Cuban Research Institute of the FIU, opens doors to a better understanding of the phenomenon of Cuban migration and a critical look at these processes. In some cases becomes a sensitive issue, where academics and power interests interrelate. It is for this reason that I join this debate on the perception of exile as a myth, with a Central European perspective. An issue investigated, among others by Safran William, and in the Cuban case by Silvia Pedraza, for example in her work Political Dissafection in Cuba's Revolution and Exodus (2007). I hope to contribute a critical look at this specific topic.

\section{Cuban migratory crisis (2014-2017)}

Crisis was how the media referred to the last Cuban migratory wave of 2014-2017 that left the island and headed for the United States of America, choosing Central America as their main gateway. ${ }^{1}$ The media drew the attention of the public opinion to the matter and forged the perception, thus affecting the collective imagination, with regards to the phenomenon. The said attitude made the migratory tragedy of human flow from the South to the North - which Central America has been witnessing for many

1 This media-spread rumour was so strong that Wikipedia created a separate entry with a Spanish title "Cuban Migratory Crisis 2015-2017", with a long list of references, available at: https:// es.wikipedia.org/wiki/Crisis_migratoria_cubana_(2015-2017). 
decades - invisible and marginalised; it succeeded in alerting the international public opinion to the social and economic issues that beset the Cuban population today, and which are the main factors that contribute to individual migratory decisions. These difficulties and issues have become significantly more pressing since the introduction of the Raúl Castro government's economic reforms aimed at the reduction of state social spending, and shifting the burden upon the "shoulders of the citizens themselves" through the liberalisation of the local economy and the expansion of the scope of private enterprise. In order to increase national economic competitiveness, Cuba needs to boost the flow of capital and people's mobility.

Apart from increasing the population's expectations in regard to welfare and quality of life, as well as the connectivity with the outside world, the recent social and economic changes have created a general air of impatience to pursue a more immediate fulfilment of individual dreams, hopes and goals. This restlessness, coinciding with the entry into force of the modifications of the Cuban migratory regulations ${ }^{2}$ and the opening of the national economy, as well as the rumours ${ }^{3}$ regarding the lifting of the U.S. "wet feet, dry feet" policy, which is the part of the Cuban Adjustment Act, propelled thousands of islanders to seek a better life outside their homeland in a process called by the media "the new exodus" or "the migratory crisis".

Since the beginning of 2013 until the end of 2017 probably over 200,00o persons left Cuba permanently or temporarily. This was facilitated by the new Cuban migratory regulations that extend the possibility of a legal stay outside the country to up to 24 months and lift the necessity to obtain a permit to leave or the requirement to present an invitation from a foreigner to the Cuban authorities (Aja Diaz et al.). This justifies the claim that between 40 and 50 thousand persons leave Cuba each year, mainly at the age of 20 to 45 , i.e. in the reproductive and economically productive age. ${ }^{4}$ Cuban statistics do not offer any details on the phenomenon and Antonio Aja, the director of the Centro de Estudios Demográficos (CEDEM) at the University of Havana, points out that: "the latest migratory changes have not been accompanied by any improvement in the gathering of statistical data" (Diario de Cuba). The impossibility to offer an exact count of the Cuban émigrés stems from the fact that Cuban authorities do not treat the persons who leave for a period of up to 24 months as migrants, but rather as residentes cubanos en el exterior (Cuban residents abroad), and do not publish statistics on the issue. Pursuant to article 9.2 of the Law No. 1312: "A Cuban citizen is considered an emigrant when they travel abroad pursuing personal affairs and stay for an uninterrupted period of

2 Law No. 1312 - Migration Law, amended by Executive Order No. 302 of 11th of October 2012, entered into force 14th of January 2013.

3 Came true in January 2017.

4 It is important to note that these are our own estimations, based on the statistical information published by the Pew Research Center, National Statistical Office of Cuba along with the Yearbook of Inmigration Statistics, published by the Government of the United States. 
more than 24 months without a corresponding authorisation, or take up residence outside the country without having complied with the current migratory regulations" (República de Cuba 616). ${ }^{5}$ The registers of the destination countries which host Cuban migrants allow for estimations which clearly indicate that the number of migrants in the years 2013-2016 was increasing year after year. The data presented by the Pew Research Center serve as an example. They reveal that in 2014 over 24,000 Cubans entered the United States (the main destination). In 2015 and 2016 this number reached 43,159 and $56,406^{6}$ respectively (Krogstad). This means that between 2014 and 2015 the entry rate of Cuban citizens into the United Stated grew by $77 \%$, which took place after the historical declaration of the heads of states Barack Obama and Raúl Castro regarding the rapprochement and the re-establishment of bilateral political relations. Nevertheless, the most recent regulations introduced by the U.S. administration, among them the abolishing of the "wet feet, dry feet law" and the reduction of visas and periods of stays, have contributed to a decrease in the number of entries. For example, during the 2017 fiscal year, U.S. Customs and Border Protection reported 15,557 cases of Cubans attempting to cross the Southeast border of the United States.

The majority of the migration flow from Cuba to the U.S. took place on land and through the points located on the American-Mexican border, e.g. 31,965 persons in Laredo, 4,911 in El Paso, and 1,434 in San Diego (Cortaya). If we compare these data with earlier information, we can confirm that the route to the United States has changed, and that the direct crossing of the sea (typical in the 1980s and 1990s) was replaced by a journey through a third-country territory. This marks a growth in prominence of the model of the re-migration flow among the Cuban migration-related phenomena, in which third countries are used as intermediaries (mostly Mexico, Panama, Ecuador, Colombia, Venezuela, and Guyana). Still, if a migrant is unable to continue the journey towards their destination or lacks the means to do so, they try to settle in the countries along their way, even if it is just a temporary arrangement. For example, according to Datosmacro.com, in 2017 there were 3,083 émigrés from Cuba in Ecuador, although in the years 2015-2016 there were 10,000 Cubans entering the country annually. This clearly indicates that these persons' goal was to reach the U.S. border via countries with less restrictive migration policies towards Cuban citizens. Today the countries that offer visa-free access to Cuban tourists include: Belarus, Serbia, Montenegro, Russia in Europe; Panama, Granada, Dominica, Guyana, Trinidad and Tobago, Saint Kitts and Nevis, St. Lucia, St Vincent \& Grenadines

5 Se considera que un ciudadano cubano ha emigrado, cuando viaja al exterior por asuntos particulares y permanece de forma ininterrumpida por un término superior a los 24 meses, sin la autorización correspondiente; así como cuando se domicilia en el exterior sin cumplir las regulaciones migratorias vigentes.

$676 \%$ of the cases involved undocumented persons invoking the "wet feet, dry feet" law of the Cuban Adjustment Act. 
in Latin America; Georgia, Cambodia, Kyrgyzstan, Kazakhstan, Qatar, Mongolia, Singapore in Asia, and Togo, Namibia, Uganda, Guinea, Kenya in Africa.

The 2015-2017 Cuban exodus was brought to public attention not only by the traditional audio-visual and print media outlets but also by the new communication channels, such as social media. Thousands of photographs and written accounts circulated around the world along with the news about the concentrations of Cuban migrants in Panama, Ecuador, Costa Rica, Nicaragua or Mexico. They presented images of Cuban emigrants waiting at border crossings in the countries along their way north, armed with cell phones, credit cards, and organised in networks and groups. This presented a striking contrast with the pictures from the past (1980s and 1990 of the $20^{\text {th }}$ century) and images of other collectives of migrants who travel through Central America and Mexico on their way to the United States.

\section{Return to Cuba: an unprecedented issue}

In the contemporary history of Cuba, especially after the year 1959, immigration was an exceptional phenomenon, since departures from the island prevailed in the panorama of the migration flow. Therefore, negative migration readings would achieve high numbers. The departures often occurred in waves. According to Jorge Duany, since 1959 more than 2 million of Cubans have emigrated to the United States, i.e. the main destination of the insular population.

Table 1. Main periods of Cuban migration to the United States, since 1959

\begin{tabular}{|l|l|c|}
\hline \multicolumn{1}{|c|}{ Period } & \multicolumn{1}{|c|}{ Characteristics } & $\begin{array}{c}\text { Number of } \\
\text { Emigrants }\end{array}$ \\
\hline January 1959 - October 1962 & $\begin{array}{l}\text { Historical exiles, after the triumph } \\
\text { of the revolution }\end{array}$ & 248,100 \\
\hline $\begin{array}{l}\text { November 1962 - November } \\
1965\end{array}$ & $\begin{array}{l}\text { Suspension of regular migration } \\
\text { after the Missile crisis }\end{array}$ & 74,000 \\
\hline December 1965 - April 1973 & $\begin{array}{l}\text { Freedom flights after closing the } \\
\text { port of Carioca }\end{array}$ & 260,600 \\
\hline April - September 1980 & The exodus from the port of Mariel & 124,800 \\
\hline October 1980 - December 1991 & Renewal of regular migration & 154,000 \\
\hline August - September 1994 & Balsero crisis & 30,900 \\
\hline May 1995 - January 2017 & $\begin{array}{l}\text { Period of the "wet-feet, dry-feet" } \\
\text { policy }\end{array}$ & 705,700 \\
\hline
\end{tabular}

Source: Duany, Jorge. "Cuban Migration: A Postrevolution Exodus Ebbs and Flows." Migration Information Source. Migration Policy Institute (2017): https://www.migrationpolicy.org/article/cuban-migration-postrevolution-exodus-ebbs-and-flows 
The constant trickle of Cuban migration abroad helped to develop and reinforce the Cuban diaspora, which today counts almost 3 million people all over the world. According to the official census, in the year 2017 in the U.S. alone, there were two million three hundred thousand Cuban-Americans. It is necessary to add to these numbers one hundred and fifty thousand Cubans in Spain, and thousands in other countries, such as Mexico, Venezuela, Brazil, Panama, Canada, Germany, Italy, France or Russia. These figures amount to $28 \%$ of the population of 11 million inhabitants of the island.

The continuous and high emigration correlated with low birth and fertility rates, coupled with an increasing life expectancy, have directly contributed to stagnation in population growth. Since the 198 os the number of inhabitants of the country has remained unchanged, oscillating around 11,200,00o people. At the same time, the ageing process was becoming ever more visible: today more than $20 \%$ of $\mathrm{Cu}$ ban population is over 65 years old, which places the country next to Uruguay and Barbados among the oldest societies in Latin America.

At the beginning of the 21st century, Cuba arrived at a cul de sac. The permanent economic crisis did not favour positive changes in the demographic processes; on the contrary, it gained in severity:

- population stagnation with very low birth and fertility rates,

- rapid population ageing,

- strongly negative migratory balance,

- continuous decrease of the labour force in the domestic market.

Since 2006 the Cuban government implemented reforms that initiated the opening of the island to the world in economic, social and political spheres. Apart from strengthening their political legitimacy, the objective of the authorities was to revive and activate the domestic labour market, stem permanent emigration, and stimulate the growth of population. The direct impact of the reforms included:

- the reduction of public employment and the expansion of legal possibilities for private employment (in 2014, there were 438,00o people who worked on their own compared to 138,000 in 2005; in 2014 the private sector employed $1 \mathrm{~m}$ people compared to 500,000 in the 2005 ). There are $4.5 \mathrm{~m}$ professionally active people in Cuba;

- following the Reform of the Migratory Law (implemented in 2013), which eliminated restrictions to external mobility for Cuban citizens, national departures increased from 300,000 in 2013 to over 700,000 in 2016;

- the possibility of land tenancy for the plots that remained barren for up to 10 years resulted in delivering almost $2 \mathrm{~m}$ hectares made available to private individuals and cooperatives since 2008;

- the modification of the General Housing Law facilitates the sale and purchase of real estate and makes it possible to let real estates to foreigners. 
Given the internal political-economic circumstances and external diplomatic relations, a drastic change took place in Cuban migration trends, as until today the migrants would seldom return. In 2013 and 2014, for the first time in decades, a positive net migration of 0.3 and 0.2 per one thousand inhabitants was reported. The values in 2013 reached 3,300 persons and a further 1,900 persons in 2014. Although in the following years the migratory rates turned negative, there were high numbers of persons who filed motions for repatriation. In the years 2013-2015 the number was 14,000; 17,000 in 2016, and 14,000 persons in 2017. Undoubtedly, it is necessary to point to the external and internal circumstances that favour decisions regarding Cubans' returns to their homeland. The number of people returning indicates that we can talk about the first phase of massive repatriation.

Before we analyse this unprecedented phenomenon, it is worth mentioning that in 2012 we carried out the scientific project entitled Quo vadis Cuba? (Dembicz 2013). With a set of interviews and surveys among the island population, and among the representatives of the diaspora - as well as in the survey scenario - we included questions about Cubans' future plans, i.a. the plans to return. Much to our surprise, the majority of young Cubans living on the island expressed the opinion that their objective was not to emigrate permanently, but rather to be able to travel outside and learn about the world and be able to return to Cuba and live there with dignity. Regarding the representatives of the Cuban emigration, especially post-1990, almost $75 \%$ declared that they wished to return to Cuba and to participate in its political and economic transformation.

Given that the Cuban government had fulfilled the initial condition for structural reforms on the island, it was predictable that mass returns to the island would follow. It is important to stress that the possibility of repatriation had existed in Cuba for many years, but only over sixty-year-olds, the sick, the helpless, or those lacking any financial means were eligible. Today, there is a law that renders all the Cubans eligible to submit a motion.

What could be the main elements of attraction for the ones who decide to return? We can classify them into three groups:

I. Subjective-individual reasons, such as:

- presence of close relatives on the island or lack of final adaptation abroad and,

- longing for the homeland.

II. General internal factors:

- favourable economic conditions for investment and professional development in private enterprises,

- the pluralisation of political, economic and social life (LGBT movement, dialogue with the opposition and civil society, an increasing role of the private sector),

- a possibility of recovering and inheriting property (especially real estate) left behind at the time of emigration, 
- the perception of the Cuban diaspora as part of the Cuban society,

- improved prospects of internal and external mobility.

III. External conditions, such as:

- the normalisation of relations with the United States and the European Union,

- a dialogue with the Organization of American States as part of a regional dialogue effort joined by Cuba in recent years,

- increasing international activity of Cuba, also in the process of Latin American and Caribbean integration.

All these elements clearly make return decisions increasingly more frequent. However, only individual stories can illustrate a person's true reasons. From my own investigative experiences, the main reason is the possibility of higher mobility for people, without the need to permanently leave the country. Today, Cubans leave the island and remain outside for up to 24 months without having to apply for special permits from national institutions. This situation has allowed thousands of persons with U.S. and Spanish citizenships, who reside in Cuba but continuously travel abroad to work, to be able to return with the money they have saved.

\section{The myth of Cuban exile}

Without any doubt, during the last decades, the profile of Cuban emigrants, as well as the factors that push them to take the decision to leave their country, have been evolving. It is no longer the politics that are the main reason for leaving the country, as in the cases of the first (1959-1962), the second (1965-1973) and the third (1980) migration waves. The 1994 Balsero crisis ${ }^{7}$ revealed to the world, and to the Cubans themselves that the main factor of their mobility was the economic situation and the lack of fulfilment of individual plans and expectations. The importance of this aspect grew in the following years - also due to the growing fear of a possible lifting of the "wet feet, dry feet law" and the potential reduction of the support awarded to Cuban immigrants by the federal government of the United States.

This situation has inspired me to rethink the history of the Cuban exile, which is related to political repressions, banishment, and a prolonged stay away from the homeland, often with no possibility of return. It is a story of more than one million Cubans who, in the years 1959-1994 reached the United States, Mexico, Spain, and other countries around the world. With time, this history served to popularise and mythologise such narratives as the one of the salsa singer and musician Willy Chirino - niño Pedro Pan (Peter Pan child), Reinaldo Arenas - the Marielito, or little Elian González - the rafter, or the stories of the imprisoned, banished

7 Normalised through the introduction of the "wet feet, dry feet" within the framework of the Cuban Adjustment Act. 
politicians and activists such as Huber Matos and Carlos Franqui. They undoubtedly owe their popularity and the living memory to the media, which also include the works of art (musical, cinema, literature) that have contributed to the shaping and the development of the story of the Cuban exile, and strengthened the identity of the Cuban diaspora. The stories of the revolutionary and Castro's dictatorship, the need to emigrate, the impossibility of return, and the longing for homeland have become a leitmotif for films, novels, and poems. Numerous examples of such works include films, such as For Love or Country (2000) about the life of the trumpet player Arturo Sandoval, The Lost City (2005) illustrating the pre-revolutionary Havana, or the Netflix series (2015) Celia about the life of Celia Cruz. The novels include: Before Night Falls by Reinaldo Arenas, which later inspired a film under the same title, Waiting for Snow in Havana by Carlos Eire, How Night Fell by Huber Matos or the Havana for a Dead Prince by Guillermo Cabrera. Also, the music contributed to the perception of the Cuban emigration as exile. Among the countless music productions we can easily point to the album 90 millas by Gloria Estefan, the song Guajiro soy by Willy Chirino, La Cuba mia, Por si acaso no regreso and De La Habana hasta aquí by Celia Cruz or Cuando salí de Cuba by Argentinian Luis María Aguilera Picca, who had lived for several years on the island, before making the decision to leave after the triumph of the Cuban revolution. We could also name paintings, sculptures, and other works of art; however, the goal is not to present an endless list of titles but to emphasise that apart from the daily coverage in the press, on the radio, and on the T.V., the world of the media has had a profound impact on the mythologisation of the events in question. Some real histories have been transformed into myths - as described by Roland Barthes in his Mythologies, where he analyses the matters from a contemporary perspective - as a result of various practices employed by the modern media. Barthes offers a very comprehensive definition of a modern-world myth. Firstly, he points out that it is a system of communication, in which a message has a specific objective. This objective may be a political, social, or market agenda. As a system of communication, a myth is subject to linguistic, visual, and representation-related conditions. Barthes himself notes that "Myth is a type of speech" (118) which cannot be defined by its purpose, but rather by its message (the words and representations that are used). Therefore any thing can become a myth, and everything can undergo mythologisation. However, unlike the ancient mythology, which transcended the limitation of its times, contemporary mythology is subject to time conditions, as it is primarily set around a well-defined objective, and is fuelled by actual events. Thus, once the source of a myth is exhausted, i.e. the real events, the myth expires. Barthes indicates specific conditions, under which a myth ends or undergoes demystification:

- a change in the environment that feeds the myth (the stories);

- a change in the linguistic that characterise the myth;

- a change in the message; 
- the deterioration of the myth, which can be recognised by the arbitrariness of its signification;

- the disappearance of the motivation.

When analysing the information on the Cuban emigration produced by the media, it is necessary to take into consideration that the second half of the $20^{\text {th }}$ century was dominated by a rivalry sparked by the Cold War. The goal of the messages created by the "Western" media, especially in the United States, was, among other things, to belittle the enemy, in this case, the Castro regime. Thus, the content and the shape of the messages, aligned with this objective, contributed to the strengthening of the myth of the Cuban exile, the impact of the political prosecution, the abandoning of the fatherland, the impossibility to return, and the longing for the home country. It is sufficient to cite I feel Cuba, a poem by Henry Maldonado, interpreted by Andy Garcia (an actor and an activist against the Cuban regime):

Imagine, imagine a morning....

A morning unlike any other morning ever since, and just like every other morning up until then

And then imagine all those mornings of the world. My world...

Gone, almost in an instant

And so begins the hunger, the hunger for memories, the hunger for family, the hunger for freedom

And everywhere... I see Cuba, I taste Cuba, I feel Cuba

And we spread out wings and take flight with a hunger to be free

Cuba, her sons and daughters spread throughout the world

And we, the sons and daughters of liberty, we infuse world with the fresh, hot blood of the New World

Her music adds rhythm, percussion, and a thrill to our lives wherever a beat is driving hearts

Because Cuba is there

Whenever food rises above mere sustenance, I smell the sweetness of a plátano, I feel the memories of ropa vieja

And family...

And Cuba is there...

When words fail me, I get lost in her literature

And I fear to ask

Will memories keep me safe? Hold me? Will they last? Will they last a lifetime or two? Or perhaps three?

Memories outlined in black and white images moving across an old movie Postcards sent long ago Kept alive by a pure will 
And faith... And the images of life so loved

Cuba is there

Liberty is a tasty dish, best served hot with courage And when I look for courage, Cuba is there.

In the halls of power, in the lonely battlefields of war, in the struggles for freedom

Cuba is there

Her influence no longer limited by borders, her ideas transcend time and space

She infuses me with a thrill for life and a longing for freedom

It is life breathing in my chest

Every day I see Cuba, every day I feel Cuba, e very day I taste Cuba

She has changed the world, my Cuba, she has changed my world, my Cuba

And someday, she promises, in a morning unlike any other, a morning unlike any ever

in the history of the world

I will lay my head on her shoulders, once more in her arms, her arms around me

And I will feel my Cuba... Here...

I will feel my Cuba, and will come home to her in freedom

Because the road to liberty is a road of fate, a road of inescapable certainty

And that road leads home to Cuba... And no-one can stop it

I will come home, home to my Cuba.

"Mi Cuba querida"'

\section{Final remarks}

While the 2oth-century world was bipolar, the subsequent century has pulled it apart and formed international relations in a multipolar and multicentric fashion. The communication in the media no longer responds to the ideological confrontation between the United States and the Soviet Union. We rather see a diversification of the origins of global competitors, which reflects the economic pragmatism and the existential reasons that blur the divisions between various political positions. Today the U.S. media (such as Radio Televisión Martí and El Nuevo Herald) have softened their criticism of the Cuban state, reflecting the current migratory tendencies and the returns to the island, as well as the shift in the discourse, leaving aside such terms a "dictatorship", and highlighting the social changes and the economic opening of the country. Also, new works of art, such as the films Habana Blues (2005), Return to Ithaca (2014) or One night (2013) contribute to the process of deconstruction of the myth of the Cuban exile. Still, the main arguments in support of the theorem on the end of the Cuban exile myth, are the current socio-economic and migratory conditions in Cuba, as well as the international situation. The changing environment has ceased to feed the myth of exile. The relations between Cuba and the rest of the world, especially the United States, have altered the tone of 
political and media discourse, thus affecting the linguistic conditions that characterise the myth. Step by step, we are witnessing a transformation of the message that kept the myth of the Cuban exile alive.

Today, no-one contests the existence of circular migration, back and forth, or the returns and the repatriation, i.e. phenomena that until now were unheard of in the case of Cuba. These elements accompany the decline of the attempts to increase the political confrontation between Cuba, the United States and the European Union, and modify the epistemological and semiotic basis that support the myth of the Cuban exile, thus bringing us closer to the conclusion that what we are observing is, in fact, the actual end of this myth as such.

\section{Works Cited}

Aja Díaz, Antonio. "La emigración cubana en los años noventa." Cuban Studies 30 (1999): 1-25.

Aja Díaz, Antonio, Rodríguez Soriano, María Ofelia, Orosa Busutil, Rebeca, \& AlbizuCampos Espiñeira, Juan Carlos. "La migración internacional de cubanos. Escenarios actuales.” Revista Novedades en Población, 13(2017): 40-57. Web. 22 May 2019 http://scielo.sld.cu/scielo.php?script=sci_arttext\&pid=S1817-40782017000200004 Barthes, Roland. Mitologías, México: Siglo XXI, 1999.

Cortaya, Rolando. "Más de 50.000 cubanos ingresaron a EE.UU. en el año fiscal 2016.” Radio Televisión Martí (October, 2016). Web. 15 March 2019 https://www. radiotelevisionmarti.com/a/mas-de-50000-cubanos-ingresaron-a-eeuu-en-elano-fiscal-2016/131276.html

Datosmacro.com “Cuba. Emigrantes totals.” (2017). Web. 15 March 2019 https:// datosmacro.expansion.com/demografia/migracion/emigracion/cuba

Dembicz, Katarzyna (Ed.). Cuba: ¿quo vadis? Warszawa: Centrum Studiów Latynoamerykańskich UW, 2013.

Diario de Cuba (DDC). "Funcionarios cubanos piden más rigor en estadísticas sobre emigración en la Isla.” (July, 2016). Web. 10 March 2015 http://www.diariodecuba. com/cuba/1468329710_23782.html

Duany, Jorge. Blurred Borders: Transnational Migration between the Hispanic Caribbean and the United States. Chapel Hill, NC: University of North Carolina Press, 2011.

Duany, Jorge. "Cuban Migration: A Postrevolution Exodus Ebbs and Flows." Migration Information Source. Migration Policy Institute (2017): Web. 15 March 2019 https://www. migrationpolicy.org/article/cuban-migration-postrevolution-exodus-ebbs-and-flows

Duany, Jorge (Ed.). Un pueblo disperse. Dimensiones sociales y culturales de la diáspora cubana. Afuana Vieja Editorial, 2014. 
Eckstein Susan, Mette Louise Berg, "Cubans in the United States and Spain: The Diaspora Generational Divide.” Diaspora: A Journal of Transnational Studies 18 1/2 (Spring/Summer 2009): 159-183.

Israel, Nico. Outlandish: Writing between Exile and Diaspora. Stanford: Stanford University Press, 2000.

Krogstad, Jens Manuel. "Surge in Cuban Immigration to U.S. Continued through 2016." Pew Research Center (January 13, 2017): Web 20 February 2019 http://www.pewresearch. org/fact-tank/2017/01/13/cuban-mmigration-to-u-s-surges-as-relations-warm/

Maldonado, Henry. I fell Cuba. (2009): Web 20 February 2019 https://www.youtube. com/watch?v=LDamBl5JvJA

Pedraza, Silvia Political Disaffection in Cuba's Revolution and Exodus. New York: Cambridge University Press, 2007.

República de Cuba. "Gaceta Oficial no. 41 Extraordinaria de 18 de diciembre 2015." (December 2015): Web. 10 April 2019 http://media.cubadebate. cu/wp-content/uploads/2017/10/Ley-No.-1312-\%E2\%80\%9CLey-deMigraci\%C3\%B3n\%E2\%80\%9D-Edici\%C3\%B3n-Actualizada.pdf

Safran, William. "Diaspora in Modern Societies: Myth of Homeland and Return." Diaspora A Journal of Transnational Studies, 1.1 (1991): 83-99. http://doi. org/10.1353/dsp.1991.000

Televisión Martí. "43.159 cubanos llegan en último año fiscal a EEUU; superan éxodo de balseros del 94,” (November 2015): Web 20 February 2019 http://www. martinoticias.com/a/mas-de-43000-cubanos-llegaron-2015-eeuu/108339.html

Katarzyna Dembicz - Ph.D., since 1992 at the University of Warsaw, currently as an associate professor in the American Studies Center. Editor-in-Chief of the scientific journal Ameryka Łacińska [Latin America]. She specialises in regional integration and social and demographic changes in Latin America and the Caribbean. In 2017 Professeur invité at the IHEA Université Sorbonne Nouvelle Paris 3. Polish National Science Centre-funded an international project: Quo vadis Cuba? Impication for Europe and Poland; at present Head of the "Discourses and development dilemmas of Central American local communities" project (Polish National Science Centre); member of the Jean Monnet Network Foro Europa-Cuba, coordinated by CIDOB Barcelona, Spain. Author of numerous academic publications, i.a. PosCuba. Lo imponderable de la transformación insular (2016); Cuba Actual y Futura. Realidad Económica y Transformación Política y Social (Foreign Affairs Latinoamérica 2014); Barboza Lizano, O. \& Dembicz, K., "Environmental Cuba versus Economic transformation”. EUROPA XXI (2017). 